\title{
Clinical, Neuroradiological and Electroencephalographic Findings of Epileptic Patients with Malformation of Cortical Development
}

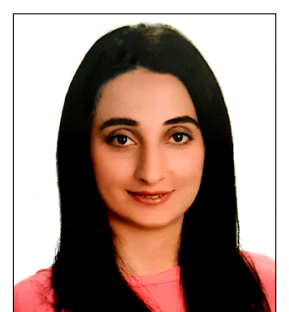

Dr. Derya BAYRAM

\section{Epilepsi ve Kortikal Gelişimsel Malformasyonu Olan Hastaların Klinik, Nöroradyolojik ve Elektroensefalografik Bulguları}

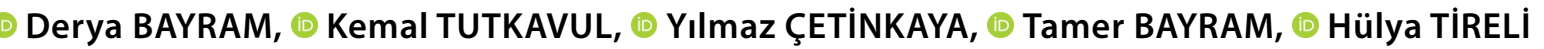

Department of Neurology, Health Sciences University Haydarpaşa Numune Training and Research Hospital, İstanbul, Turkey

\begin{abstract}
Summary
Objectives: We aimed to review the clinical, neuroradiological and electroencephalographic (EEG) findings of patients with epilepsy and malformation of cortical development (MCD).

Methods: A retrospective analysis of the medical records of epilepsy outpatients was done. Patients with epilepsy, MCD, and $\geq 18$ years of age were included and classified according to the Barkovich classification (BC).

Results: The files of 2027 patients were assessed, and 17 out of 1395 epilepsy patients who were followed-up were found to have MCD. The mean age was 26.5 years. Ten patients were male and 7 were female. The mean time of seizure onset was 13 years. In terms of seizure type, 11 patients had focal, 10 had generalized tonic-clonic, 1 had absence, 1 had tonic-atonic, and 1 had myoclonic. MRI showed 7 patients with cortical dysplasia, 4 with heterotopia, 2 with periventricular nodular heterotopia, 2 with schiezencephaly, 2 with lissencephaly, 1 with agyria, 1 with pachygyria, 1 with macrogyria, 1 with polymicrogyria, and 1 with tuberous sclerosis. EEG revealed focal epileptiform discharges in 5 patients, high-frequency activity in 2, generalized epileptiform discharge in 1, diffuse disorganized background activity in 1, and focal disorganized background activity in 1. EEG was normal in 7 patients. Four of them were on monotherapy and 13 on polytherapy.

Conclusion: The MCDs classified in group 1 and 2 according to BC are more frequent. Treatment-resistant or good responsive cases can be seen and seizures can begin at any age. We concluded that the prevalence of MCD is $1.21 \%$. The spectrum of epilepsy seen is extensive and the most common type of MCD is focal cortical dysplasia.
\end{abstract}

Keywords: Epilepsy; malformation of cortical development; polytherapy.

\section{Özet}

Amaç: Epilepsi ve kortikal gelişimsel malformasyonu (KGM) olan hastaların klinik, nöroradyolojik ve elektroensefalografik (EEG) bulgularını gözden geçirmektir.

Gereç ve Yöntem: Epilepsi polikliniği tıbbi kayıtları geriye dönük olarak incelendi. Epilepsi, KGM ve yaşı $\geq 18$ olan hastalar dahil edildi ve hastalar Barkovich sınıflamasına (BC) göre gruplandıııldı.

Bulgular: İki bin yirmi yedi hasta dosyası incelendi. Takibe devam eden ve epilepsi tanısı konan 1395 olgunun 17'sinde KGM saptandı. Hastaların yaş ortalaması 26.5 yıl idi. Hastaların 10'u erkek, yedisi kadındı. Nöbet başlangıç yaşları ortalaması 13 yıl idi. Olguların 11 'inde fokal, 10 'unda jeneralize tonik klonik (JTKN), birinde absans, birinde tonik-atonik, birinde miyoklonik nöbet saptandı. MRG'de yedi hastada kortikal displazi, dört hastada heterotopi, iki hastada periventriküler noduler heterotopi, iki hastada şizensefali, iki hastada lizensefali, bir hastada Tubero skleroz, bir hastada agiri, bir hastada pakigiri, bir hastada makrogiri, bir hastada polimikrogiri vardı. EEG'leri değerlendirildiğinde beşinde fokal epileptiform deşarj, ikisinde hızlı ritim, bir hastada jeneralize epileptiform deşarj, bir hastada fokal organizasyon bozukluğu, bir hastada yaygın organizasyon bozukluğu, görülmüştür. Yedi hastanın EEG'leri normaldi. Hastaların üçü monoterapi, 14'ü politerapi altında idi.

Sonuç: BC'ye göre grup 1 ve 2'ye giren KGM'lere daha sık rastlanmaktadır. Tedaviye dirençli veya iyi cevap veren olgular görülebilir ve nöbetler her yaşta başlayabilir. Prevalans \%1.21 bulundu. Görülen epilepsi spektrumu geniştir ve en sık karşılaşılan KGM tipi fokal kortikal displazidir.

Anahtar sözcükler: Epilepsi; kortikal gelişimsel malformasyon; politerapi.

Submitted (Geliş): 21.05.2018

Accepted (Kabul) : 06.11.2018

Correspondence (illetişim): Derya BAYRAM, M.D.

e-mail (e-posta): deryak_30@hotmail.com 


\section{Introduction}

In the developing brain tissue, an interruption in the neuronal or glial proliferation, migration, and organization constitute malformations of cortical development (MCD). MCD is being recognized as an important underlying cause of developmental delay, epilepsy, and other neurological disorders in human beings. The incidence of cerebral cortical developmental abnormalities is not known exactly but the frequency of MCD is thought to be $1 / 100000 .{ }^{[1]}$

Development of the central nervous system, between the $2^{\text {nd }}$ month and the perinatal period of pregnancy, requires the completion of many complex cellular processes. Any failure of this mechanism results in the development of some malformations. The most recent developmental event is myelination, which lasts until adulthood. ${ }^{[2]}$ The exact cause of MCD is unknown but consideration of genetic and environmental factors is important. Many people being affected in the same family has led to the idea that genetic factors may be involved in the etiology of MCD.

In recent years, genetic defects (LIS1, DCX, RELN, ARX, 143-3E, EMX2, POMT1, etc.) have been reported in some patients. ${ }^{[3-5]}$ Environmental factors such as placental ischemia, intrauterine CMV infection, ionizing radiation, $\mathrm{CO}$ poisoning, and early gestational bleeding seriously affect neuronal migration. ${ }^{[6-8]}$ Apart from prenatal events, there is information that neonatal periventricular hemorrhage and early postnatal traumas also cause dysplastic lesions. ${ }^{[9,10]}$

\section{Materials and Methods}

\section{Design}

We conducted a retrospective analysis of the medical records of patients from the epilepsy outpatient clinic who were followed-up between July 1995 and January 2015.

\section{Sample}

Patients who had epilepsy and radiological diagnosis of MCD on their MRI and who were $\geq 18$ years of age were included in the study. Patients whose diagnosis was in doubt were excluded. MRI scans had been done with a $1.5 \mathrm{~T}$ scanner which included standard 3-D (sagittal, axial and coronal) images. MRI studies included conventional T1/T2-weighted studies, inversion recovery, and fluid-attenuated inversion recovery acquisitions.

\section{Analysis}

Current patient age, seizure onset age, type of epilepsy, use of anticonvulsant drugs, EEG and MRI findings, family history, and other pathologies were assessed.

Patients were classified into 3 main groups according to the Barkovich classification (BC): "Malformations due to abnormal cell proliferation" (G1), "Malformations due to abnormal migration" (G2), and "Malformations due to abnormal cortical organization" (G3). ${ }^{[11,12]}$

\section{Method of evaluation}

Mean values of age and time of seizure onset were calculated. The type of MCD and associated age of seizure onset, seizure frequency, and used drugs were presented. The results were compared with past literature.

\section{Results}

The files of 2027 patients were assessed, and 17 out of 1395 epilepsy patients who were followed-up were found to have MCD. The mean age was 26.5 years (range: 18-54 years). Ten patients were male and 7 were female. The mean time of seizure onset was 13 years (range: 3 months-22 years).

Detailed information about the patients is shown in Table 1. In terms of seizure type, 11 patients had focal, 10 had generalized tonic-clonic, 1 had absence, 1 had tonic-atonic, and 1 had myoclonic. Syndromic classification revealed 12 patients with symptomatic focal epilepsy, 3 with symptomatic generalized epilepsy, 1 with Dyke-Davidoff syndrome, and 1 with juvenile myoclonic epilepsy (JME) phenotype.

MRI showed that 7 patients had cortical dysplasia, 5 had heterotopia, 2 had periventricular nodular heterotopia (Fig. 1), 2 had schizencephaly, 2 had lissencephaly, 1 had agyria, 1 had pachygyria, 1 had macrogyria, 1 had polymicrogyria (Fig. 2), and 1 had tuberous sclerosis. There were also some patients who had more than one MCD subtype.

EEG revealed focal epileptiform discharges in 5, high-frequency activity in 2, generalized epileptiform discharge in 1 , focal disorganized background activity in 1 and diffuse disorganized background activity in 1 . The EEG was normal in 7 patients. 
Table 1. Detailed information about the patients

\begin{tabular}{|c|c|c|c|c|c|c|}
\hline Patient & $\begin{array}{c}\text { Patient } \\
\text { malformation }\end{array}$ & $\begin{array}{c}\text { Age of } \\
\text { seizure onset }\end{array}$ & $\begin{array}{l}\text { Frequency of } \\
\text { seizure }\end{array}$ & $\begin{array}{l}\text { Type of } \\
\text { seizure }\end{array}$ & Drugs & $\begin{array}{l}\text { EEG } \\
\text { findings }\end{array}$ \\
\hline 1 & Heterotopia (G2A) & 13 years & 3-4 times in a week & FS\GTCS & Valproic acid & FED \\
\hline 2 & Cortical dysplasia (G1) & 19 years & No seizure for 13 years & FS & Carbamazepine & Normal \\
\hline 3 & $\begin{array}{l}\text { Lissencephaly (G2B) } \\
\text { Agyria, pachygyra }\end{array}$ & 10 months & Once in 2 months & $\begin{array}{l}\text { FS } \backslash G T C S \backslash \text { tonic- } \\
\text { atonic S. }\end{array}$ & $\begin{array}{c}\text { Carbamazepine } \\
\text { Topiramate } \\
\text { Pregabalin }\end{array}$ & HFA \\
\hline 4 & $\begin{array}{c}\text { Lissencephaly (G2B) } \\
\text { Macrogyria }\end{array}$ & 20 years & Once in a month & GTCS & $\begin{array}{l}\text { Valproic acid } \\
\text { Levetiracetam }\end{array}$ & HFA \\
\hline 5 & Cortical dysplasia (G1) & 16 years & 1-2 times in a year & GTCS Imyoclonic S & $\begin{array}{l}\text { Valproic acid } \\
\text { Levetiracetam }\end{array}$ & Normal \\
\hline 6 & Cortical dysplasia (G1) & 3 years & 3-4 times in a year & FSIGTCS & Levetiracetam & Normal \\
\hline 7 & $\begin{array}{l}\text { Periventricular nodular } \\
\text { Heterotopia }(\mathrm{G} 2 \mathrm{~A})\end{array}$ & 21 years & 2 times in a week & FS & $\begin{array}{c}\text { Carbamazepine } \\
\text { Topiramate }\end{array}$ & Normal \\
\hline 8 & $\begin{array}{c}\text { Heterotopia (G2A), } \\
\text { Schizencephaly (G3A) }\end{array}$ & 3 years & 3-4 times in a day & FS\GTCS & $\begin{array}{c}\text { Valproic acid } \\
\text { Levetiracetam } \\
\text { Topiramate }\end{array}$ & FED \\
\hline 9 & Cortical dysplasia (G1) & 20 years & Once in 2 months & FS & $\begin{array}{l}\text { Carbamazepine } \\
\text { Levetiracetam }\end{array}$ & Normal \\
\hline 10 & Polymicrogyria (G3A) & 1 years & $2-3$ times in a week & FS & $\begin{array}{l}\text { Valproic acid } \\
\text { Levetiracetam } \\
\text { Carbamazepine }\end{array}$ & FED \\
\hline \multirow[t]{7}{*}{11} & Heterotopia (G2A) & 14 years & Once in a week & GTCS & $\begin{array}{c}\text { Carbamazepine } \\
\text { Lamotrigine }\end{array}$ & GED \\
\hline & $\begin{array}{c}\text { Heterotopia (G2A), } \\
\text { Schizencephaly (G3A) }\end{array}$ & 18 years & Once in a week & GTCS & $\begin{array}{l}\text { Levetiracetam } \\
\text { Lamotrigine }\end{array}$ & GDBA \\
\hline & $\begin{array}{c}\text { Tuberous sclerosis (G1) } \\
\text { Heterotopia }(\mathrm{G} 2 \mathrm{~A})\end{array}$ & 22 years & Once in a month & FS & $\begin{array}{l}\text { Valproic acid } \\
\text { Levetiracetam }\end{array}$ & FDBA \\
\hline & $\begin{array}{l}\text { Periventricular nodular } \\
\text { Heterotopia }(G 2 A)\end{array}$ & 3 months & $5-6$ times in a month & FS & $\begin{array}{l}\text { Topiramate } \\
\text { Vigabatrin }\end{array}$ & FED \\
\hline & Cortical dysplasia (G1) & 13 years & Once in a month & FS & Carbamazepine & Normal \\
\hline & Cortical dysplasia (G1) & 20 years & 2-3 times in a day & FS & $\begin{array}{c}\text { Valproic acid } \\
\text { Levetiracetam } \\
\text { Carbamazepine }\end{array}$ & FED \\
\hline & Cortıcal dysplasia (G1) & 17 years & 3-4 times in a year & GTCS Iabsence S. & Valproic acid & Normal \\
\hline
\end{tabular}

MCD subtype according to BC scheme, Group 1(G1): "Malformations due to abnormal cell proliferation"; Group 2 (G2): "Malformations due to abnormal migration", and Group 3 (G3): "Malformations due to abnormal cortical organization" G2A: Group 2A; G2B: Group 2B; G3A: Group 3A; G3C: Group 3C; S: Seizure; FS: Focal seizure; GTCS: Generalized tonic clonic seizure; FED: Focal epileptiform discharges; GED: Generalized epileptiform discharges; HFA: High frequency activity; FDBA: Focal disorganized background activity; DDBA: Diffuse disorganized background activity.

Mental retardation was present in 5 patients and autism was seen in 2.

Family history of epilepsy was present in 8 patients, consanguinity in 5 , head trauma in 2 , and history of difficulty during delivery in 1 .

Four patients were on monotherapy but 13 of them were on polytherapy.

\section{Discussion}

Reviewing clinical, neuroradiological and electroencephalographic (EEG) findings of patients with epilepsy and MCD was the aim of this study. Although the true prevalence of MCD in patients with epilepsy is not known, our study revealed a prevalence of $1.21 \%$. It was found to be $3 \%$ in the prospective study of Everitt et al. ${ }^{[13]}$ In the study by Papayannis et al.., ${ }^{[14]}$ where all patients had MRI scans with a 

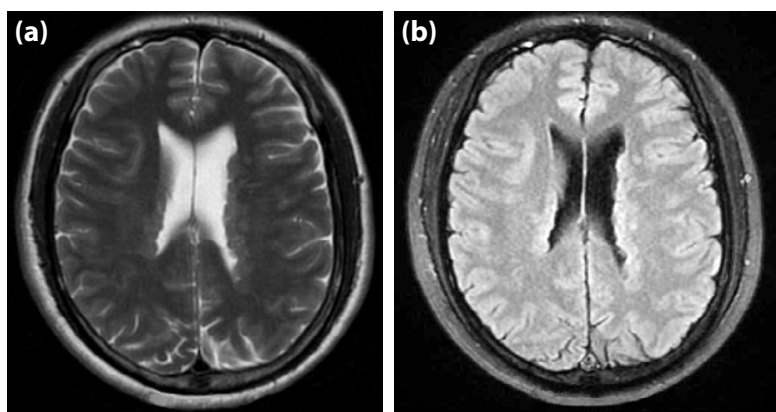

Fig. 1. (a, b) Periventricular nodular heterotopia areas are seen in the neighborhood of both lateral ventricles (this patient showed normal EEG with focal seizures).
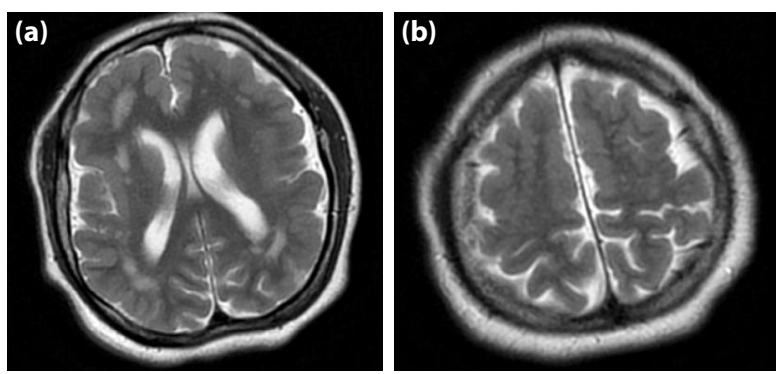

Fig. 2. (a, b) At the level of bilateral frontoparietal lobes, cortical irregularity, irregularity in cortical gray-white matter region, and small irregular gyrus occurrences were evaluated as polymicrogyria. T2A and FLAIR series was seen in the subcortical white matter of frontoparietal regions as multiple, focal, small, longitudinal and ovoid hyperintensities without sharp borders (this patient showed focal epileptiform discharges on EEG and had focal seizures).

3.0 T or $1.5 \mathrm{~T}$, there were $152(5.06 \%)$ cases with MCD from a total of 3000 patients with epilepsy. The prevalence of MCD could differ between different countries due to the social conditions of study populations, use of low-high resolution magnetic resonance imaging techniques, and ages of the study populations.

Many different classification systems for MCD and focal cortical dysplasia (FCD) have been introduced to date. Taylor et al. ${ }^{[15]}$ first described FCD in patients with drug-resistant epilepsy who underwent surgical resection in 1971. Mischel et al. ${ }^{[16]}$ proposed a neuropathologic grading system including balloon cells, heterotopia, polymicrogyria, neurons in the molecular layer, and cortical disorganization in 1995. Barkovich et al. described a classification system for MCD according to MRI analysis in 1996 and 2005. In many epilepsy centers, the Barkovich classification is widely used. One of the leading classification systems used for focal cor- tical dysplasia is the Palmini classification of FCD (based on histopathologic findings) published in 2004, recently replaced by a newer classification, the Blümcke ${ }^{[17]}$ classification of focal cortical dysplasia in 2011. This system reviews the clinical, imaging, genetic, and especially histopathologic understanding of FCDs. The classification supported by ILAE and written by Task Force commissions was not used in our study because it required histopathologic data and included only FCD.

Barkovich et al. ${ }^{[11,12]}$ presented an updated version of the developmental and genetic classification of MCD in 2012. A detailed assessment of MRI features allowed us to classify participants based on MCD subtype into 3 groups as they are easier to detect by MRI. In our study, the histopathologic data of patients after surgery were not available because the patients that we thought suitable for surgery were directed to the relevant centers. The distribution of our patients according to BC was as follows: 8 patients (47.1\%) were in group 1, 9 patients (53\%) in group 2, and 3 patients (17.6\%) in group 3. Group 1 was diagnosed as having FCD and tuberous sclerosis. Group 2 included patients with periventricular nodular heterotopia $(\mathrm{PNH})$, subcortical heterotopia, mixed forms of heterotopia, and lissencephaly. Group 3 included cases with polymicrogyria (PMG) and schizencephaly. In their study, Papayannis et al. ${ }^{[14]}$ found the distribution of cases according to the BC was: $51.4 \%$ in group $1,28.9 \%$ in group 2 and $19.6 \%$ in group 3 . Liu et al. ${ }^{[18]}$ revealed that $29 \%$ of their patients were classified in group $1,41 \%$ in group 2, and $24 \%$ in group 3. Gestational and perinatal insults in different countries vary. Also, the number and age of population included in the studies affect the distribution of MCD subtypes. These factors may explain the differences in results between studies. Although the $B C$ allows us to group patients according to MRI findings, certain diagnoses are possible only with histopathologic data.

MCD is often accompanied by epileptic seizures and can be recognized by brain MRI. They can lead to severe epileptic encephalopathies and drug-resistant focal or generalized epilepsy. In the present study, a majority of the seizures were focal. Eleven out of 17 patients in our study had focal seizures.

The spectrum of seizures in patients with $M C D$ is quite variable. Although MCD is the underlying cause of most of the severe and treatment-resistant epilepsy cases in children 
and adults, it is possible that patients with MCD do not show resistant epilepsy. ${ }^{[19]}$ In our study, 11 patients had a seizure frequency of once a month or more. Only 1 patient who had cortical dysplasia had been seizure-free for 13 years with carbamazepine treatment.

The most common type of MCD in this study population was FCD (41.2\%). A recent study observed relatively late epilepsy onset in 150 epilepsy patients with MCD in western China and reported that the most common type of MCD was FCD (29\%) as well. ${ }^{[18]}$ According to this study, patients with simple MCD (patients had a deformity of a single characteristic MCD in the absence of other malformations) had lower seizure frequency. The multiple MCD group (patients had MCD associated with additional cerebral malformations) experienced seizures more often. These results were similar to our study. We also observed that patients with multiple malformations had more frequent and antiepileptic drug-resistant seizures. These patients mostly had daily or weekly seizures.

The clinical presentation time of patients with epilepsy could begin at any age but it mostly begins in the first or second decade of life, usually after the age of 2-3 years. ${ }^{[20]}$ In our study, 5 out of 17 patients had their first seizure at 3 years or younger. The explanation of why 12 out of 17 patients had a seizure onset after 3 years of age could be that most patients with an earlier seizure onset are followed-up by a pediatric neurologist and only some of them survive till adulthood. The mean time of seizure onset was 13 years in our study, which was similar to the study by Papayannis et al. (12.3 years of age).

The patient with the highest seizure onset time in our study, which was at 22 years, had heterotopia and literature also supports us in terms of the clinical age onset of epilepsy in this pathology. Heterotopias are known to have high epileptic potential and can remain silent until adulthood. ${ }^{[21,22]}$ On the other hand, our patient with the earliest seizure onset time, which was at 3 months, had heterotopia.

As a consequence of the association of MCD with drug-resistant epilepsy, polytherapy is necessary for many patients. [23] Thirteen of our patients received polytherapy. On the contrary, MCD can sometimes cause late-onset and good drug-responsive seizures. Three of our patients with cortical dysplasia and 1 with heterotopia took monotherapy.
Interestingly, a case of a patient with JME phenotype and MRI-detected FCD has been recorded by Oguni, where he mentioned about difficulties to differentiate idiopathic generalized epilepsies from symptomatic epilepsies and gave an example of a boy 4-year-old who had epilepsy with myoclonic-astatic seizures. His brain MRI showed right FCD and he had clinical and EEG patterns similar to myoclonic-astatic seizures. ${ }^{[24]}$ On the other hand, Carney et al. ${ }^{[25]}$ showed 2 patients with absence epilepsy and PNH in their study and investigated whether $\mathrm{PNH}$ is associated with absence seizures using EEG-functional MRI. This study demonstrated that the periventricular nodules can show connectivity to the absence network and may be involved in seizure generation. If we could have performed EEG-fMRI to our patient who was diagnosed with JME phenotype and FCD, we would have seen whether FCD was connectivity to the JME network or not.

Scalp EEG in patients with MCD can either be normal or it can show focal or generalized epileptiform discharges, background slowing, or localized high-frequency activity. The most frequent EEG findings in our patients were focal epileptiform discharges and high-frequency activity. Localized high-frequency activity is reported to be associated with some MCDs like cortical dysplasia and lissencephaly. [22,26] The EEG in 2 of our patients showed high-frequency activity. One of these patients had lissencephaly with agyria and pachygyria complex, and the other one had lissencephaly with macrogyria on MRI.

It is usually difficult to control seizures in patients with MCD. Wide-spectrum antiepileptic drugs such as valproic acid and their combinations are used for drug therapy-resistant cases. Eight patients in our study were taking antiepileptic drugs including valproic acid and its combinations. Most of our patients were under polytherapy. Selected patients can be offered surgical intervention. Patients with some forms of MCD such as polymicrogyria are not good surgical candidates because their condition can be multifocal or bilateral. ${ }^{[17]}$ A recent study by Pasca et al. ${ }^{[27]}$ that included 45 patients showed that a ketogenic diet might be effective in reducing seizure frequency in patients with drug-resistant epilepsy and MCD after surgery is deemed not viable. Abnormal neural migration and abnormal post-migrational development had the best response with seizure frequency reduction of $>50 \%$ and $>64.7 \%$, respectively. Also, a patient with polymicrogyria and a patient with microlissencephaly 
remained seizure-free after undertaking a ketogenic diet. In addition, seizure outcome following surgery is variable with seizure-free rates in $30 \%-90 \%$ of MCD series. ${ }^{[28-30]} \mathrm{A}$ study by Radhakrishnan et al. ${ }^{[31]}$ in which $66.67 \%$ of patients were seizure-free after surgery for at least the preceding 2 years, showed that a majority of patients with drug-resistant epilepsy and MCD were seizure-free when operated upon early. Also, a shorter duration of epilepsy was the most important pre-operative variable and absence of spikes in postoperative EEG may also predict a long-term favorable seizure outcome. Based on this information, we thought that it should be emphasized that surgery is preferable in possible patients and the ketogenic diet can be used in patients who are not suitable for surgery.

In the study by Papayannis et al., ${ }^{[14]} 5.1 \%$ of the cases had a family history of epilepsy or other neurological diseases. Interestingly, 8 patients (47.1\%) in our study have a family history of epilepsy. The number of patients evaluated in the study should be higher to make an analysis of accompanying disorders and consanguinity in family history.

\section{Limitations}

This study was a retrospective evaluation and had its characteristic restrictions. The sample size of the study was very small. It is known that among patients with drug-resistant epilepsy, MCD can be detected in the histopathologic evaluation of some operated patients because the supporting clinical and technical evaluation in the brain MRI is negative, however, there are no negative brain MRI cases in our study. We also do not have the histopathologic data of some patients who were referred to centers of epilepsy surgery. Another limitation of this study is the developing technology. With $3 T \mathrm{MRI}$, the MCD could be visible in epileptic patients as well as a normal 1.5 T MRI study.

\section{Conclusion}

In this retrospective hospital-based study, the prevalence of MCD in patients diagnosed with epilepsy was $1.21 \%$. The rate we found was not close to the previous studies ${ }^{[13,14]}$ which may be a consequence of different study populations and study design. The clinical presentation time of epilepsy in patients with MCD varies considerably. Majority of the seizures were focal and most patients required polytherapy. The most common type of MCD in this study population is FCD and the most frequent EEG findings are focal epileptiform discharges and high-frequency activity.

\section{Peer-review}

Externally peer-reviewed.

\section{Conflict of interest}

The authors declare that they have no conflict of interest.

\section{Authorship Contributions}

Concept: K.T.; Design: K.T., D.B.; Supervision: T.B., H.T.; Materials: D.B., Y.C..; Data collection \&/or processing: D.B., T.B.; Analysis and/or interpretation: T.B.; Literature search: D.B., K.T.; Writing: D.B., K.T.; Critical review: H.T.

\section{References}

1. Leventer RJ, Guerrini R, Dobyns WB. Malformations of cortical development and epilepsy. Dialogues Clin Neurosci 2008;10(1):47-62.

2. Volpe JJ. Neuronal proliferation, migration, organization, and myelination. In: Neurology of the Newborn. 3rd ed. Philadelphia: WB Saunders, 1995. p. 43-92.

3. Kato M, Dobyns WB. Lissencephaly and the molecular basis of neuronal migration. Hum Mol Genet 2003;12:R89-96. [CrossRef]

4. Uyanik G, Aigner L, Martin P, Gross C, Neumann D, MarschnerSchäfer $\mathrm{H}$, et al. ARX mutations in X-linked lissencephaly with abnormal genitalia. Neurology 2003;61(2):232-5.

5. Guerrini R, Marini C. Genetic malformations of cortical development. Exp Brain Res 2006;173(2):322-33. [CrossRef]

6. Uher BF, Golden JA. Neuronal migration defects of the cerebral cortex: a destination debacle. Clin Genet 2000;58(1):16-24.

7. Barkovich AJ, Gressens P, Evrard P. Formation, maturation, and disorders of brain neocortex. AJNR Am J Neuroradiol 1992;13(2):423-46.

8. Hayward JC, Titelbaum DS, Clancy RR, Zimmerman RA. Lissencephaly-pachygyria associated with congenital cytomegalovirus infection. J Child Neurol 1991;6(2):109-14.

9. Sarnat HB. Disturbances of late neuronal migrations in the perinatal period. Am J Dis Child 1987;141(9):969-80. [CrossRef]

10. Palmini A, Andermann E, Andermann F. Prenatal events and genetic factors in epileptic patients with neuronal migration disorders. Epilepsia 1994;35(5):965-73. [CrossRef]

11. Barkovich AJ, Kuzniecky RI, Jackson GD, Guerrini R, Dobyns WB. A developmental and genetic classification for malformations of cortical development. Neurology 2005;65(12):1873-87.

12. Barkovich AJ, Guerrini R, Kuzniecky RI, Jackson GD, Dobyns WB. A developmental and genetic classification for malformations of cortical development: update 2012. Brain 2012;135(Pt 5):1348-69. [CrossRef]

13. Everitt AD, Birnie KD, Stevens JM, Sander JW, Duncan JS, Shorvon SD. The NSE MRI study: Structural brain abnormalities in adult epilepsy patients and healthy controls. Epilepsia 1998;39(2):140.

14. Papayannis CE, Consalvo D, Kauffman MA, Seifer G, Oddo S, D'Alessio $L$, et al. Malformations of cortical development and epilepsy in adult patients. Seizure 2012;21(5):377-84. 
15. Taylor DC, Falconer MA, Bruton CJ, Corsellis JA. Focal dysplasia of the cerebral cortex in epilepsy. J Neurol Neurosurg Psychiatry 1971;34(4):369-87. [CrossRef]

16. Mischel PS, Nguyen LP, Vinters HV. Cerebral cortical dysplasia associated with pediatric epilepsy. Review of neuropathologic features and proposal for a grading system. J Neuropathol Exp Neurol 1995;54(2):137-53. [CrossRef]

17. Blümcke I, Thom M, Aronica E, Armstrong DD, Vinters HV, Palmini A, et al. The clinicopathologic spectrum of focal cortical dysplasias: a consensus classification proposed by an ad hoc Task Force of the ILAE Diagnostic Methods Commission. Epilepsia 2011;52(1):158-74. [CrossRef]

18. Liu W, An D, Xiao J, Li J, Hao N, Zhou D. Malformations of cortical development and epilepsy: A cohort of 150 patients in western China. Seizure 2015;32:92-9. [CrossRef]

19. Guerrini R, Sicca F, Parmeggiani L. Epilepsy and malformations of the cerebral cortex. Epileptic Disord 2003;5 Suppl 2:S9-26.

20. Kuzniecky RI, Barkovich AJ. Malformations of cortical development and epilepsy. Brain Dev 2001;23(1):2-11. [CrossRef]

21. Yapıcı Z, Gürses C. Serebral kortikal gelişimsel anomaliler ve epilepsi. In: Epilepsi. Bora İ, Yeni N, Gürses C, editors. 1st ed. İstanbul: Nobel Tıp Kitabevi; 2008. p. 409-14.

22. Yapııı Z, Topaloğlu-Tektürk P, Uludüz D. Çocukluk Çağı Semptomatik Nöbetleri. Epilepsi 2014;20:49-52. [CrossRef]

23. Crino PB. Focal Brain Malformations: a spectrum of Disorders along the mTORCascade. Department of Neurology. Universy of Pennsylvania Medical Center. Novartis Foundation Sympo- sium, 288. 2007:260-72, discussion 272-81. [CrossRef]

24. Oguni H. Symptomatic epilepsies imitating idiopathic generalized epilepsies. Epilepsia 2005;46 Suppl 9:84-90. [CrossRef]

25. Carney PW, Masterton RA, Gill D, Jackson GD. Nodular heterotopia and absence seizures: $\mathrm{FMRI}$ evidence that they may be connected. Epilepsy Res 2013;106(3):451-5. [CrossRef]

26. Güngör S, Yalnızoğlu D, Topçu M. Kortikal Gelişimsel Malformasyonlar. Çocuk Sağlığı ve Hastalıkları Dergisi 2007;50:210-25.

27. Pasca L, Caraballo RH, De Giorgis V, Reyes JG, Macasaet JA, Masnada $S$, et al. Ketogenic diet use in children with intractable epilepsy secondary to malformations of cortical development: A two- centre experience. Seizure 2018;57:34-37. [CrossRef]

28. Cohen-Gadol AA, Ozduman K, Bronen RA, Kim JH, Spencer DD. Long-term outcome after epilepsy surgery for focal cortical dysplasia. J Neurosurg 2004;101(1):55-65. [CrossRef]

29. Kral T, Clusmann H, Blümcke I, Fimmers R, Ostertun B, Kurthen $M$, et al. Outcome of epilepsy surgery in focal cortical dysplasia. J Neurol Neurosurg Psychiatry 2003;74(2):183-8. [CrossRef]

30. Fauser S, Schulze-Bonhage A, Honegger J, Carmona H, Huppertz HJ, Pantazis $G$, et al. Focal cortical dysplasias: surgical outcome in 67 patients in relation to histological subtypes and dual pathology. Brain 2004;127(Pt 11):2406-18. [CrossRef]

31. Radhakrishnan A, Menon $R$, Menon D, Singh A, Radhakrishnan $\mathrm{N}$, Vilanilam $\mathrm{G}$, et al. Early resective surgery causes favorable seizure outcome in malformations of cortical development. Epilepsy Res 2016;124:1-11. [CrossRef] 